\title{
A PEDAGÓGUSSZAKMA ÉS -PÁLYA NÉPSZERÜSÍTÉSÉNEK TECHNIKÁI A NEMZETKÖZI GYAKORLATBAN: ELMÉLETI ALAPOK, KUTATÁSI KÉRDÉSEK, HORIZONTÁLIS ELEMZÉSI EREDMÉNYEK
}

\section{GORDON GYÖRI JÁNOS* - OLÁHNÉ TÉGLÁSI ILONA ** - ÜTŐNÉ VISI JUDIT ${ }^{* * *}$}

* Eszterházy Károly Főiskola Tanárképzési és Tudástechnológiai Karának és az Eötvös Loránd Tudományegyetem Pedagógiai és Pszichológiai Karának habilitált egyetemi docense gyori.janos@ektf.hu

** Eszterházy Károly Főiskola Természettudományi Karának adjunktusa olahneti@ektf.hu

*** Eszterházy Károly Főiskola Tanárképző Központjának föiskolai docense judit.uto.visi@gmail.com

\begin{abstract}
A Pedagógusképzés következö három tanulmánya egy TÁMOP-kutatás részeredményeit mutatja be. A feltáró jellegü kutatás során a pedagógusszakma és -pálya népszerüsitésének stratégiáit és technikáit vizsgáltuk tíz ország keretében, országonként tizennégy szempont mentén. Az összegyüjtött adatokból részint az egyes oktatási rendszerek egészét átfogó országtanulmányokat, részint pedig tematikus elemzéseket készitettünk, valamint az oktatáspolitika által használható javaslatokat fogalmaztunk meg közel száz pontban. Gordon Győri János, Oláhné Téglási Ilona és Ütöné Visi Judit irásának első részében a kutatás kérdéseit, elméleti kereteit és módszertanát foglalják össze, a második részben pedig egy olyan összehasonlitás eredményeit ismertetik, amelynek során Magyarországot és kilenc másik országot négy szempontból vetették össze a kutatási témában.
\end{abstract}

\footnotetext{
1 Jelen tanulmány a TÁMOP-4.1.2.B.2-13/1-2013-0010 Új stratégia a pedagóguspálya hazai népszerüsítésére c. projekt keretében, a pedagógusszakma és -pálya népszerüsítése nemzetközi tapasztalatainak összehasonlító elemzése alapján készült. Elkészítésében nagymértékben támaszkodtunk a kutatás során készült háttértanulmányokra, amelyeknek szerzői a témát feldolgozó kutatócsoport tagjai voltak: Bárdos Jenö, Czók Brigitta, Györi János (kutatásvezető), Majorosné Kovács Györgyi, Mogyorósi Zsolt, Oláhné Téglási Ilona, Tarnóc András, Ütőné Visi Judit, Virág Irén.
} 


\section{A kutatás koncepcionális és módszertani alapjai}

A TÁMOP-projekt keretében végzett kutatásunk során azt kívántuk feltárni, hogy Európán belül és kívül mi jellemzi a társadalmakat és az oktatási rendszereket a pedagóguspálya népszerüsítése szempontjából, és ez miként viszonyul a jelenleg müködő vagy a jövőben kívánatos hazai gyakorlathoz. Kutatásunk idő keretei és pénzügyi korlátai nem tették lehetővé, hogy olyan alapkutatást végezzünk, amely feltárja, hogy az egyes társadalmakban és oktatási rendszerekben milyen elemekböl áll össze a pedagóguspálya „népszerüsége”, a népszerüség fogalma és jelentése az egyes oktatási kultúrákban milyen episztemológiai konstrukciókra épül, milyen diskurzusokban hogyan manifesztálódik, és ezek miként hatnak a gyakorlatban a pedagóguspálya népszerüségének különféle vonatkozásaira. Így mindezeket adottnak tekintettük, mondván, hogy a pedagóguspálya népszerüségét egyszerủen az fejezi ki, mennyire szívesen választják egy társadalom bizonyos csoportjainak tagjai a tanárképzést és a pedagógus tevékenységet élethivatásul. A ,pedagóguspálya népszerüségének" társadalmi-kulturális konstrukcióira, ennek összetevőire, arra, hogy ezekhez miként viszonyulnak egyes emberek és a társadalom különféle csoportjai az oktatás különféleképpen konstruált és müködő világaiban, csak visszakövetkeztettünk, például olyanféle adatokból, hogy hányan jelentkeznek tanárképzésbe egyegy oktatási rendszerben, kik jelentkeznek tanárképzésbe, szociológiai kutatások alapján milyen az adott országban a pedagógusszakma presztízse, demográfiailag milyen összetételü egy-egy ország tanári közössége és hasonlók.

Alapvetően három kérdés állt kutatói érdeklődésünk fókuszában:

- Az egyes oktatási rendszerekben milyen implicit elemek (például a nyári szabadság) járulhatnak hozzá a tanári szakma és pálya népszerüségéhez? (Ezeket implicit elemeknek tekintettük, mert létrehozásuknak, múködtetésüknek nem az volt a célja, hogy népszerübbé tegyék a pedagógushivatást, de a hatásuk hozzájárulhat ahhoz, hogy ez így legyen.)

- Nemzetközileg milyen direkt eszközökkel (például fizetésemeléssel, speciális kedvezményekkel) igyekeznek az oktatáspolitikusok népszerübbé tenni a tanári szakmát és pályát? (Ezeket explicit elemeknek tekintettük, mert például a fizetések rendezését az oktatásirányítók gyakran direkt módon azzal a feltett szándékkal hajtják végre, hogy vonzóbbá tegyék a pedagógusi munkát.)

- Milyen módon zajlik minderről a kommunikáció a tömegkommunikáció digitális és nem digitális formáiban?

Mindezt annak érdekében tekintettük át nemzetközi perspektívában, hogy megfelelően tudjuk értelmezni a jelenlegi hazai helyzetet ebben a tekintetben, és alkalmasint megfelelö inputtal tudjunk hozzájárulni ahhoz, hogy a hazai fejlesztések a jövőben megfelelő irányokban, módszerekkel és hatékonysággal haladjanak e téren. 
Mivel kutatásunk célja alapvetően rendszerelemző jellegü feltárás volt, ugyanakkor a hazai gyakorlat fejlesztése érdekében jó gyakorlatok keresését is célunkul tüztük ki, ezért olyan kutatási módszert választottunk, amely e céloknak kölcsönösen megfelel. A közgazdasági/piaci kutatásokban alkalmazott összehasonlitó rendszerértékelés (industrial benchmarking) olyan kutatási, elemzési és egyben tervezési eszköz, amely arra alkalmas, hogy a gazdaság (az ipar) egy szereplöjét össze lehessen hasonlítani a versenytársak legjobbjaival és akár más iparági szereplőkkel is, majd az összehasonlítás eredményeiből versenyképesség-növelő stratégiákat lehessen kialakítani. Munkánk során az industrial benchmarking Tucker (2008) által oktatási kutatásokra adaptált változatát használtuk, amely hét lépésböl áll, és mi több-kevesebb következetességgel követtük ezeket:

1. A tanulmányozandó országok kiválasztása: Kutatásunk nemzetközi részéhez kilenc országot választottunk, amelyeket páros csoportokba rendeztünk:

a) Egyesült Államok - Anglia;

b) Ausztria - Németország;

c) Finnország - Hollandia;

d) Japán - Szingapúr;

e) Szerbia - Magyarország.

Az országok nem nyelvi okokból kerültek egymással párba, hanem sokkal inkább az oktatási kultúráik közelségének okán, ami feltételezésünk szerint e társadalmak, valamint azok oktatásügye fejlödéstörténetének rokonságaiból, egymásra hatásából adódik. Így egyrészt módunk nyílt páros összehasonlításokra, másrészt az egész minta összehasonlítására a magyarországi képpel. Ugyanakkor arra is törekedtünk, hogy a hazai, illetve az európai gyakorlattól lényeges elemekben elütő rendszereket is megvizsgáljunk, mint amilyen például az Egyesült Államok, ahol az elmúlt idők során a pedagógusok értékelését a tanulói teljesítményekhez kötötték.

2. Szakirodalom-feltárás, adattár készitése és elemzése: nem volt módunk célzott feltáró látogatásokat tenni a kilenc célországba, ezért a szakirodalmi feltárásra a szokásosnál is nagyobb hangsúly helyeződött. Annak érdekében, hogy az összehasonlítások számára megfelelő adattárat hozzunk létre, a feltáró kutatást 14, valamennyi ország esetében egységesen alkalmazott szempont szerint végeztük el. Ezekböl mutatunk be tanulmányunk későbbi pontján négyet.

3. A kiválasztott országokon belüli szakmai kapcsolatok kiépitése; legalább egy, szakmailag releváns helyi személy bevonása a munkába: a helyi szakmai kapcsolat kiépítésére Tucker nagy hangsúlyt helyez, hiszen ez a személy az, aki a kutatások, szakirodalmi leírások adatait valóban kontextuálisan el tudja helyezni, azok torzításait (a saját, de reflektált torzításai segítségével is) ki tudja egyensúlyozni, az ismereteket élettel tudja meg- 
tölteni, de akár kreatív továbbfejlesztési elgondolásai is lehetnek. A kontakt személy a helyi nyelv ismeretében is előrébb jár, mint a kutatócsoport más tagjai, akik nem anyanyelvüek. Mi ugyancsak éltünk ezzel a lehetöséggel: valamennyi ország esetében az adott helyen magas szakmai elismertségnek örvendő szakemberekkel müködtünk együtt, országonként legalább eggyel.

4. A kutatás és értelmezés fogalmi keretének kidolgozása: a fogalmi keretek kidolgozása minden kutatás esetében döntő jelentőségü, és így volt ez a mi munkánk esetében is. E helyütt nincs mód arra, hogy az általunk alkalmazott fogalmi keret minden elemét bemutassuk, néhányat azonban röviden ismertetünk A kutatás és értelmezés fogalmi kerete címü fejezetben.

5. A kutatócsoport összeállitása megfelelő szakemberekböl: esetünkben a kutatócsoport tagjai ugyanazon tanárképzési mühely tagjai voltak, valamenynyien az Eszterházy Károly Föiskola szakemberei, ami a munka szakmai homogenitásának kulcseleme volt.

6. A kutatócsoport tagjainak felkészitése az egyes országok adott téma szerinti tanulmányozására: az általunk alkalmazott módszerben ez azt jelenti, hogy a kutatás központi személyei összeállítanak valamennyi ország legfőbb jellemzőiből egy közös anyagot, könyvet vagy hasonló produktumot, és mielött elkezdődik a munka, ezzel minden kutató megismerkedik. Számunkra ez logisztikai okokból kivitelezhetetlen volt, így minden munkacsoporttag maga állította össze magának az általa feltárandó ország kontextuális alapinformációit, és ezt a munka későbbi fázisában megosztottuk egymással.

7. Az adatgyüjtés során elegendő idő biztositása: megfelelő időt kell biztosítani a megértés rendezett, rendezetlen és - egy magasabb megértési szinten - újrarendeződő állapotainak megfelelő váltogatódására; a mozaikok minél teljesebb képpé való összedolgozására. Feltáró kutatásoknál ez alapvető fontosságú: időt kell hagyni arra, hogy az anyag elrendeződjék és újra „szétessen”, az újabb ismeretek és megértések lévén lehessen, sőt szükséges legyen ismételten, de már másmilyen rendszerbe összeilleszteni öket. Esetünkben ez kevésbé „drámaian” zajlott, mint ahogy azt Tucker leírása érzékelteti, de jelen volt a munkánkban.

\section{A kutatás és értelmezés fogalmi kerete}

Pedagógusszakma - pedagóguspálya

Feltáró munkánk során mindvégig következetesen elkülönítettük, a pedagógusszakmát és a pedagóguspályát - amelyek ugyan szorosan összefüggnek egymással, hatnak egymásra, lényegüket tekintve mégis más-más dimenziót jelentenek. A peda- 
gógusszakma alatt azt a kompetenciarendszert értettük, amellyel egy pedagógus munkát végző személy a formális tanárképzésnek köszönhetően rendelkezik vagy rendelkeznie kellene, illetőleg azokat a tevékenységformákat, cselekvéseket, amelyek ebből következnek. Például azt, hogy valaki ismeri a fejlődéstan alapjait, „ért a gyerekek nyelvén”, ügyesen megtervez egy órát, jó technikákkal, módszerekkel rendelkezik a tanítás terén és hasonlók.

A tanári pálya ugyanakkor az a társadalmi konstruktum, amely tulajdonképpen azt jelöli ki, hogy ha valaki formálisan képzett, diplomás tanárként kíván dolgozni egy oktatási rendszerben, milyen (jogi, anyagi, munkavégzési stb.) keretek között fogja tudni ezt megtenni munkaéletének rövidebb-hosszabb szakaszai során.

Értelmezésünkben a pedagógusszakma formális elsajátításának kerete a felsőoktatási tanárképzés valamely változatában, és - a leggyakoribb esetben - mindaddig tart, amíg diplomával, vagyis megfelelő certifikációval rendelkezve valaki a pedagóguspályára nem lép. A pedagóguspálya pedig a munkába állással kezdődik, és mindaddig tart, amíg az illető ezt a munkát végzi valamilyen oktatási szervezeti keretben.

Hipotetikusan azt feltételeztük a munkánk során, hogy ha valaki számára vonzó a pedagógusszakma, akkor számára jobb eséllyel lesz vonzó a pedagóguspálya is, mintha nem így lenne. És fordítva: ha valakinek vonzó a pedagóguspálya, akkor jó okkal feltételezhető, hogy el fogja fogadni, hogy ehhez a pedagógusszakma elsajátításán (vagyis a formális tanárképzésen) keresztül vezet az út, vagyis az ott felajánlott tudásrendszernek, kompetenciakészletnek stb. a megismerésén, elsajátításán keresztül. Ezért és így, ebben az összefüggésrendszerben értettük úgy, hogy e két dimenzió szorosan összefügg és egymásra utalt, noha különböző entitások.

\section{Rekrutáció - retenció}

Amikor a pedagógusszakma és -pálya népszerüségét annak érdekében kívánjuk megérteni, hogy megtudjuk, milyen módszerekkel lehet népszerüsíteni ezeket, akkor tulajdonképpen azon gondolkozunk, miként lehet elérni, hogy a pedagógusszakma és -pálya választására ösztönözhessünk (megfelelö) személyeket. Ezt hívjuk pedagógus rekrutációnak, toborzásnak. Amikor viszont egyes személyek, annak köszönhetően, hogy számukra a pedagógusszakma és -pálya megfelelően vonzó, ezeket a lehetőségeket választják, (tehát belépnek a tanárképzésbe, illetőleg megkezdik pedagógusi karrierjüket), akkor a szakma és a pálya népszerüsége már azonnal egy másik szempontból válik fontossá, nevezetesen abból a szempontból, hogy megfelelően „népszerüek”, vonzóak tudnak-e lenni ahhoz, hogy ezek a személyek ott is maradjanak. Vagyis például ne hagyják el a tanárképzést valamilyen más tudásrendszer elsajátítása érdekében, vagy például hogy ne hagyják el a tanári pályát egy másik professzió érdekében. Ezt hívjuk a pedagógusszakma és -pálya retenciójának, megtartó képességének. 
Mindezeknek köszönhetően munkánk során egy négyosztatú mátrixban dolgoztunk, amelyben minden elem mindig kétszer ismétlődik, és mi valamennyi oktatási rendszer esetében mind a négy elemet szisztematikusan megvizsgáltuk:

- a pedagógusszakmára, annak elsajátítására való rekrutáció (a tanárképzés népszerüsítése);

- a pedagógusszakma elsajátítására vonatkozó retenció (a tanárképzés népszerüségének fenntartása annak érdekében, hogy a tanárképzésben részt vevő személy ne hagyja el a tanárképzést valamilyen más, számára vonzóbbnak látszó képzési lehetőség vagy a munka világa érdekében);

- a pedagóguspályára vonatkozó rekrutáció (a pedagóguspálya népszerüsítése annak érdekében, hogy a pedagógusképzést elvégző személyek a pedagógusi pályát válasszák, ne pedig más mesterséget üzzenek);

- a pedagóguspálya retenciója (vagyis a pedagóguspálya népszerüségének fenntartása annak érdekében, hogy aki ezen a pályán helyezkedett el, az a pályán is maradjon, mert a pályaelhagyás nagy veszteség - jelentős hatékonyságcsökkenés - az egész rendszerre vonatkozóan).

\section{Presztízs}

Az e téren zajló vizsgálatok jellemzően szociológiai indíttatású kutatások, így ezekből legalább két, számunkra fontos dimenzió hiányzik, illetve másképp épül fel, mint ahogy a mi kutatásunk számára érdekes vagy fontos volt:

- Az ilyen jellegü munkák gyakran nem különítik el, hogy a presztízst a szakma vagy a pálya szempontjából vizsgálják-e. Lehet például a tanári szakma, a tanári tudásrendszer presztízse magas egy társadalomban, miközben a tanári pálya presztízse valamilyen oknál vagy okoknál fogva alacsony (például mert alacsonyak a jövedelmi viszonyok; vagy ugyanígy a fordítottja is lehet).

- Fontos volt számunkra, hogy a szakma/pálya presztízskonstrukcióját egy összetettebb rendszerben kezeljük, mint ahogy az általában a szociológiai kutatásokban megjelenik, ezért elkülönítettük az alábbiakat:

o a pedagógusszakma aktuális társadalmi presztízse;

o a pedagóguspálya aktuális társadalmi presztízse;

o a pedagógusszakma személyes presztízse valamely egyén esetében, amely mind negatív, mind pedig pozitív irányban jócskán különbözhet a társadalmilag és statisztikailag azonosítható presztízstől, és amely meghatározza az egyén döntését, hogy belép-e a tanárképzés rendszerébe;

o a pedagóguspálya személyes presztízse;

o a pedagógusi szakma társadalmilag kívánatos presztízse (amely az oktatáspolitikusok számára fontos ismeret a szakmát népszerüsítő tevékenységformák megtervezéséhez, kivitelezéséhez);

o a pedagóguspálya társadalmilag kívánatos presztízse. 
Tehát egy olyan komplex konstruktumban igyekeztünk megragadni a pedagógusszakma/pálya presztízsrendszerét, mint amelyet például Hoyle (2001) alkalmazott, más-más entitásként azonosítva egy adott tudásterület/foglalkozás presztízsét, társadalmi státusát és az ehhez kapcsolódó értékfelfogásokat.

\section{Általános és specifikus vonások}

A fentiek talán érzékeltetik, hogy a pedagógusszakmáról és -pályáról írottak egyik korlátja az, hogy a pedagógusszakma és -pálya mint általános dolog jelenik meg bennük. Ezzel szemben az igazán fontos oktatáspolitikai kérdések vagy az egyének döntéseit befolyásoló jellegzetes dilemmák nem vagy nemcsak ezen az általános szinten jelennek meg, hanem egy egész sor konkrétabb szinten is, valóban egyének és társadalmi csoportok dilemmáiként, mint például a következőkben:

- valamely tantárgy szakmai és tanáripálya-presztízse (pl. matematika, orosz, testnevelés, forgácsolástan stb.);

- valamely iskolafokozat szakmai és pályapresztízse (pl. óvodapedagógia, egyetemi oktatás stb.);

- valamely tanulói populáció szakmai és pályajellemzői (pl. vidéki, lány, cigány, bevándorló, középosztálybeli, tehetséges, átlagos képességú stb.);

- a pedagógusi szakma és pálya valamely településhez kapcsolható jellemzői (vidéki, városi stb.);

- $\quad$ az adott szakma megismeréséhez és az adott pálya választásához szükséges végzettséget biztosító intézmények (főiskola, egyetem, szakképzés stb.).

\section{A pedagógusi szakmaiság}

Egyik munkájában Linda Darling-Hammond (2008) a pedagógusi szakmaiság négy típusát azonosítja, mintegy a tanári szakmaiság történeti változásainak periódusai szerint különítve el az egyes modelleket. A négyféle szakmaiság négyféle felkészítést igényel a tanárképzés során, és négyféle oktatási keretet vizionál:

- A hivatalnok jellegü pedagógusi szakmaiság. Eszerint elég egyszer megtanítani a leendő tanároknak mindent, a tudásanyag és a módszerek a pálya egésze során nem változnak.

- A professzionális pedagógusi szakmaiság. A tanárképzés során a kutatási készségeket és a tanár szakmai önfejlesztésének készségeit kell kifejleszteni; a tanár egész életében tanul, $\mathrm{s}$ az új és új kihívásoknak megfelelően képes állandóan fejleszteni önmagát, önmaga pedagógusi tevékenységét a kreatív, változni képes tanulók képzése érdekében.

- A piacorientált pedagógusi szakmaiság. A tanárképzés során elsősorban azt a készséget kell kialakítani, hogy a leendő tanár mindig képes legyen a megrendelő igényeinek megfelelően alakítani a tudásrendszerét, munkamódszereit stb. a piacorientált készségekben jól kidolgozott, merész, 
vállalkozó szellemü, a piaci igényekhez mindig hatékonyan alkalmazkodni tudó jövő generáció kinevelése érdekében.

- A demokratikus pedagógusi szakmaiság. A szociális és a biológiai/fizikai környezetéért felelősséget érző pedagógus képzése a cél, aki a társadalmi integráció és a környezettel való harmonikus együttélés terén is elkötelezett személy - hasonlóan elkötelezett, felelősségérzettel rendelkező, elkötelezett tanulók nevelése érdekében.

Témánk szempontjából fontos volt megértenünk, hogy a pedagógusszakma és -pálya népszerüsítése akkor tud hatékony lenni, ha összhangban van a következő generációk neveléséről alkotott társadalmi, oktatásügyi, oktatáspolitikai víziókkal, vagy legalábbis megfelelően tud utalni arra, hogy mik lehetnek a következő időszakok megfelelő víziói. Az e téren történő „elcsúszások” jelentősen csökkenthetik a népszerüsítő módszerek hatékonyságát, például ha egy társadalomban, egy oktatási rendszerben a laikus személyek vagy a szakemberek azt hangsúlyozzák, hogy a jövő nemzedékének kreatívnak, piaci értelemben bátornak, jól képzettnek kell lennie, míg az oktatáspolitikusok a hivatalnok típusú tanári szakmaiságot hangoztatják népszerüsítő anyagaikban.

\section{Generációs jellemzök}

A generációs jellemzők kutatásunk szempontjából, a rendszerfeltárások és a stratégiai átgondolások során legalább két aspektusból voltak fontosak. Az egyik az, hogy a célcsoportba tartozó személyek milyen tanári szakmaiság- és pályaképpel rendelkeznek, illetőleg az oktatáspolitikusok szerint milyennel kellene, hogy rendelkezzenek, hiszen ez nagymértékben befolyásolja a pedagógusi szakma és pálya népszerüsítésének tartalmát, technikáit (lásd Tarnóc András tanulmányát a jelen folyóiratszámban). A másik, majdhogynem döntő tényező: a célcsoportokkal, az oda tartozó személyekkel milyen kommunikációs csatornákon keresztül, milyen módon lehet, érdemes, célszerü kommunikálni - például (és mindenekelőtt) internetes anyagokkal vagy más technológiák segítségével.

\section{A horizontális kutatás eredményei}

Tanulmányunk következő részében, kutatásunk egy részeredményét ismertetendő, a pedagóguspálya és -szakma népszerüsítésének szempontjából vizsgált 9+1 országot hasonlítjuk össze négy szempont mentén, úgymint:

1. a pedagógusszakma és -pálya népszerüsége a tanári mesterségre képzés előtt (szakmába vonzás; pre-pályaválasztás; rekrutáció);

2. a pedagógusszakma és -pálya népszerüsége a tanári mesterségre történő képzés során (szakmára felkészítésben, pályára előkészítésben; retenció); 
3. a pedagógusszakma és -pálya népszerüsége a tanári pályára lépés elött (de már a képzés kifutásakor - valódi pályaválasztás; rekrutáció);

4. a pedagógusszakma és -pálya népszerüsége a tanári pályára lépést követően, a szakma gyakorlása során (retenció).

A horizontális elemzés apropóját az adja, hogy a pedagógusszakmára és -pályára orientálás fenti négy szakaszában más-más célcsoportok jelennek meg, ennek köszönhetően a PR eszközök, népszerüségnövelő stratégiák is különbözőek. PR célcsoportok: középiskolások; felsőoktatási hallgatók; a felsőoktatást elvégzők; + késői pályára lépők; + karrierváltók; praktizáló tanárok.

\section{A pedagógusszakma népszerüsitése a pedagógusképzésbe kerülés előtt}

Jelentős különbségek mutatkoztak a vizsgált országokban a középiskolások pedagógusképzésbe vonzása tekintetében aszerint, hogy az adott helyen milyen mértékü a pálya ellátottsága.

Azokban az országokban, ahol nincs tanárhiány, erős szelekciós mechanizmusok jelennek meg: az általunk vizsgált országok közül ilyen például Finnország, Japán, Szingapúr. Ezekben az országokban jellemző a túljelentkezés, ezért a képzésbe csak a legjobbak kerülnek be. Nyilvánvaló ennek összefüggése a tanári pálya magas presztízsével, társadalmi megbecsültségével, viszont nincs összefüggésben az oktatás centralizáltságával: a finn decentralizált rendszerben éppúgy megjelenik a képzés előtti szelekció, mint az erősen centralizált japán és szingapúri rendszerben. Annak ellenére, hogy ezekben az országokban túljelentkezés van, itt is találkozhatunk olyan népszerüsítő programokkal, amelyek a fiatalokat a képzésbe vonzzák: jó példa erre a japán televíziós sorozat, mely a tanárok életéről szól, valamint olyan reklámfilmszerű vizuális meggyőző anyagok, amelyek azt mutatják be, hogy milyen egy jó tanár. Mindhárom országban különleges felvételi vizsgával szürik ki a legrátermettebb jelentkezőket.

Finnországban például az érettségi vizsgával lehet bekerülni a felsőoktatásba, de pedagógusképzés esetén ez kiegészül szóbeli egyéni és csoportos interjúval, melyen vizsgálják a jelöltek kommunikációs, kooperatív képességeit, pedagógiai szituációkban való viselkedésüket, motivációjukat, pályaképüket, empátiás képességüket. Nagy hangsúlyt fektetnek a csoportos interjúra, melyen azt vizsgálják, hogyan tudnak a jelentkezők számukra többnyire ismeretlen társaikkal együttmüködni jellegzetes iskolai helyzetekben. Ezért a sikeresen felvételizőkre jellemző, hogy támogatják egymást, jó a kooperációs képességük, teret adnak mások gondolatainak kifejtésére - ezek olyan kompetenciák, melyek megadják az alapot ahhoz, hogy később sikeres tanárokká válhassanak. Itt is árnyaltabb képet kapunk azonban, ha szétválasztjuk az általános iskolai „osztálytanító” munkára felkészítő képzést a felsőbb évfolyamok szaktanári képzésével: míg az előbbi képzés népszerüsé- 
ge töretlen, az utóbbi esetében már megjelenik az a nemzetközi tendencia, hogy a természettudományos tárgyak, a matematika, illetve az informatika tanítását arányaiban kevesebben választják.

Japánban az erősen centralizált és standardizált rendszernek köszönhetően a jelölteket öt területen mérik fel, és csak a legjobbak kerülhetnek be a képzésbe - amely országosan öt pedagógusképző intézményben folyik. Szingapúr helyzete hasonló a centralizáltságot tekintve, a felsőoktatásba a kétéves ,junior college"okból kerülhetnek a hallgatók. Szigorúan meg van határozva, hogy hány hallgatót vehetnek fel a képzésbe, amely egyetlen intézményben folyik, ezért a szóbeli felvételi vizsgán itt is csak a legrátermettebbek kerülnek be. Az alapképzésböl is csak a legjobb 30 százalék kerülhet a tanári mesterképzésbe, szóbeli alkalmassági vizsga után. A felvételinél megjelenik többek között az önkéntes tevékenység keretében végzett pedagógiai munka, szakkörök, korrepetálások vezetése, tehetséggondozás.

Azokban az országokban ellenben, ahol tanárhiánnyal küzdenek (Anglia, USA, Ausztria, Németország, Hollandia), természetesen sokkal gyengébb a szelekció: Ausztriában bevezettek ugyan egy önreflexiós és külső értékelésen alapuló alkalmassági vizsgát, de alapvetően a középiskolai eredmények alapján kerülnek a hallgatók a pedagógusképzésbe (ami abból fakad, hogy bár van felvételi vizsga, de az nem szelektál). Változatos népszerüsítő programokat dolgoznak ki a fiatalok számára. Ezek legjellemzőbb módja a különböző népszerüsítő és tájékoztató portálok. Ausztriában és Németországban a „Career Counselling for Teachers” (CCT $\left.{ }^{2}\right)$ programon keresztül tájékoztatják a jelentkezőket a szükséges előfeltételekről, a képzés tanulmányi kínálatáról, a foglalkoztatási lehetőségekröl. Itt megjelennek a tanári pályát népszerüsítő cikkek, interjúk is. Mivel Ausztriában és Németországban is jellemző, hogy a tanári pályán egyre több az idős pedagógus, ezért különösen nagy hangsúlyt fektetnek a fiatalok megnyerésére. Például a CCT portálon keresztül próbálják őket azon szakokra orientálni, amelyeken a legnagyobb a hiány: a matematika és a természettudományos tanárképzés felé. Angliában a „School experiences" programmal, illetve a Gap-programmal próbálják az érettségizetteket bevonni a pedagógusképzésbe: ezek keretében iskolai hospitálásokkal, foglalkozások tartásával, beszélgetésekkel, illetve külföldön végzett önkéntes - jellemzően szociális jellegü - munkákkal próbálják a fiatalokat a pedagógusképzés irányában orientálni. A ,,Staff room” nevü portál segít a népszerüsítésben azzal, hogy bemutatja a tanári pálya szépségeit és nehézségeit, megkönnyítve a valós helyzetfelmérést, a „Premier Plus" program pedig a tehetséges diákokat hivatott megnyerni a matematika, természettudományos és informatika tanárképzésbe. Az Egyesült Államokban az elmúlt évtizedben több olyan kormányzati programot is indítottak, amely a tanári pályára vonzza a fiatalokat. Ennek legnépszerübb formája a $T E A C H$ program, ahol a széles adatbázisnak és folyamatos fejlesztésnek köszönhetően sok-

${ }^{2}$ URL: http://www.cct-germany.de/ Letöltés ideje: 2016. 01. 02. 
rétủ információhoz lehet jutni a bekerülés feltételeiről, a képzésekröl, a munkalehetőségekről - gyakorlatilag személyre szabottan megnézheti a jelentkező, hogy számára melyik képzés lenne a legmegfelelőbb - tantárgy, képzési szint, területi, nemzetiségi eloszlás stb. szerint.

Az általános népszerüsítés mellett több országban is megjelenik egyes speciális területek népszerüsítése is. A már említett matematika, informatika és természettudományos tanárképzésbe vonzás mellett például Németországban nagy hangsúlyt kap a férfi hallgatók megnyerése a tanári pályára, a pálya elnőiesedése miatt, de a migrációs vagy más nyelvi/etnikai kisebbségi háttérrel rendelkező tanulókat is megcélozzák a népszerüsítő portálok. Hollandiában a migránsok gyerekeinek tanításához nemzetköziesítéssel próbálnak külföldi diákokat bevonzani a pedagógusképzésbe. Az Egyesült Államokban szintén nagy erőfeszítéseket tesznek az indián, afroamerikai, spanyol ajkú diákok körében a tanári pálya népszerüsítésére. Szerbiában a magyar nyelvü tanárképzést próbálják népszerüsíteni például anyanyelvi érettségi és felvételi vizsga lehetőségével, kormányzati ösztöndíjakkal, tanulmányi versenyekkel, illetve magyar tannyelvủ pedagógusképzéssel.

Hollandiában, Angliában, az Egyesült Államokban és Szerbiában is támogatják a más szakmából tanári pályára lépés lehetőségét: átképzésekkel, pedagógiai és pszichológia kurzusok kínálatával, a korábbi munkatapasztalat figyelembe vételével, vagy például az Egyesült Államokban a ,substitute teacher” - helyettesítő tanár programmal.

\section{A pedagógusszakma népszerüsitése a képzés alatt}

Bár a vizsgált országokban a pedagógusképzés formái jelentős eltéréseket mutatnak, általában a képzések kétszintúek (BA-BSc/BEd és MA-MSc), de az oktatás színterei szerint változó diplomával bocsátják ki a hallgatókat a pályára: van, ahol az alapfokú oktatásban elegendő a BSc vagy föiskolai diploma (pl. Ausztria, Hollandia, Japán, Szerbia), míg máshol csak mesterszintü diplomával lehet tanítani ezen a szinten is (pl. Finnország, Szingapúr).

A képzés során - a belépők nagy elhivatottságának, az erős képzési és/vagy pályára kerülési szelekciós mechanizmusoknak köszönhetően - a lemorzsolódás nem jellemző Finnországban, Japánban és Szingapúrban. Mindhárom országban fontosnak tartják a magas szintủ tanárképzés fenntartását, és ehhez minden segítséget meg is adnak. Finnországban a lemorzsolódás inkább a képzés diszciplináris részén jelenik meg, és nagy gondot fordítanak arra, hogy azokat a hallgatókat, akiknek problémáik adódnak, támogassák, próbálják a képzésben benntartani. Szingapúrban a képzést teljes egészében az állam finanszírozza, ösztönzik a hallgatókat a külföldi (föleg angol nyelvü) képzésekben való részvételre, cserében bizonyos időt kötelezően a hazai oktatásban kell a végzetteknek dolgozni. 
Jelentős az elméleti képzés mellett a tanítási gyakorlat szerepe Németországban, Finnországban, Hollandiában, Angliában és az Egyesült Államokban. Tanítási gyakorlatot természetesen minden országban teljesíteniük kell a hallgatóknak, de például Japánban ez mindössze három hét. Ausztriában épp most van átalakulóban a felsőoktatás - és ezzel együtt a tanárképzés -, a duális képzésből az egységes, osztatlan képzés felé. Viszonylag hamar kerülnek iskolába a hallgatók a képzés során Angliában, Hollandiában, Finnországban és az Egyesült Államokban. Ezekben az országokban fokozatosan vezetik be a hallgatókat az iskolai munkába, jellemzöen gyakorlóiskolai vagy a partner iskolai rendszerben. Az utóbbi években Németországban is jelentősen megnövekedett a szakmódszertan és a gyakorlati képzés aránya, ehhez országos partneriskolai hálózatot kellett létrehozni, amelynek keretében az iskolákat érdekeltté tették abban, hogy fogadják a hallgatókat.

Szinte mindegyik vizsgált országban növekszik az átképzések aránya, de ennek formái igen különbözőek. Finnországban például az egyetemek diszciplináris képzésén jól teljesítő és pedagóguspályára alkalmasnak ítélt hallgatókat igyekeznek átirányítani tanárképzésbe. Hasonló, a tanári pályát népszerüsítő program a felsőoktatásban részt vevők számára Angliában a ,Golden Hello” portál $l^{3}$, valamint az, hogy az alapképzésben megszerezhető a „képesített tanár státusz” (Qualified Teacher Status). Hollandiában, Szerbiában, Szingapúrban, az Egyesült Államokban és Angliában is programokkal ösztönzik a más pályáról pedagógus pályára lépni szándékozókat. Elismerik a korábbi (jellemzően MSc, MA) diplomájukat, pedagógiai, pszichológiai, módszertani kurzusokkal lehetővé teszik, hogy viszonylag rövid idő alatt pedagógiai pályára léphessenek. Ilyen például Angliában a „Teach First” program jellemzően a hátrányos helyzetű tanulókat oktatására készülő hallgatók számára. Finnországban, az Egyesült Államokban nagy hangsúlyt fektetnek a speciális igényü tanulók tanításának képzésére, legyenek ezek a tanulók valamely etnikai csoportokhoz tartozók, bevándorlók vagy a sajátos nevelési igényü (SNI-s) gyerekek - ehhez külön kurzusokat indítanak.

Az egyetemeken sok helyen megjelentek a karrier portálok, irodák: ezek célja, hogy felvilágosítást nyújtsanak a tanári pályáról, segítsék a hallgatók elhelyezkedését, karriertanácsokat adjanak. Ausztriában és Németországban ilyen például a már említett CCT portál, illetve Németországban még hasonló a „Monitor Lehrerbildung" online hírlevél. Az Egyesült Államokban számos más forrás mellett a TEACH portál $l^{6}$ hivatott tájékoztatni a hallgatókat az elhelyezkedési lehetőségekről a szak, a képzési szint, a tanítás nyelve, a területi megoszlás, a tanítandó tanulók korosztálya, etnikai háttere és még sok egyéb szempont szerint. Szerbiában az

\footnotetext{
${ }^{3}$ URL: https://www.feadvice.org.uk/want-work-sector-i-want-be-teacher-fe-incentives-new-teachers/ fe-golden-hello-scheme Letöltés ideje: 2016.01.02.

${ }^{4}$ URL: http://www.teachfirst.org.uk/ Letöltés ideje: 2016. 01. 02.

${ }^{5}$ URL: http://www.monitor-lehrerbildung.de/web/ Letöltés ideje: 2016. 01. 02.

${ }^{6}$ URL: https://www.teach.org/ Letöltés ideje: 2016. 01. 02.
} 
egyetemek karrierirodáin keresztül biztosítanak a hallgatók számára olyan kurzusokat, beszélgetéseket gyakorló tanárokkal, karrier-tanácsadást, melyek a pálya iránti elkötelezettséget és a későbbi munkavállalásukat segítik. A pálya iránti elkötelezettséget erősíti az a tendencia is, amely Finnországban és az Egyesült Államokban jelenik meg a pedagógusképzés során: a tanítás és kutatás összekapcsolása. A hallgatók megfelelő képzést kapnak ahhoz, hogy leendő tanári munkájukat, illetve például a pedagógiai tevékenységet vagy a neveléstudomány kérdéseit szélesebben értve is kutatni és erre építve fejleszteni tudják. A hallgatókat arra ösztönzik, hogy már a tanárképzésük idején pedagógiai kutatásokban vegyenek részt, kurzusokat tartsanak kutatásmódszertanból, ezzel is elősegítve azt, hogy a diploma megszerzése után a tanítás mellett kutatásokba, és esetleg PhD-képzésbe kezdjenek. Fontos megemlíteni, hogy ezek a kutatások az Egyesült Államokban alapvetöen a pedagógus saját osztálytermében végzett, a saját pedagógiai munkáját vagy az iskolája munkáját fejlesztő kutatásokat jelentik (practitioner research, classroom research).

A pedagóguspálya megkezdése a végzettség megszerzése után - a valódi pályaválasztás

A diploma megszerzése még nem garancia arra, hogy a végzett pedagógus a pályára is lép, tehát a következő szint, ahol a pedagóguspályát népszerüsíteni szükséges, a valódi pályaválasztás ideje: a felsőoktatásból kilépő korosztály. Nemzetközi kutatások is alátámasztják, hogy a pályaelhagyás egyik jellemző ideje a pályán eltöltött első egy-két év után van. Sok esetben a pedagógus diplomával rendelkezők nem a szakmában helyezkednek el. Erre a legkirívóbb példa az Egyesült Államokban, ahol a végzettek 30-50 százaléka, illetve Japán, ahol a 60 százaléka keres más jellegü munkát, Igaz, a két országban e jelenségnek jelentősen eltérő a hatása: míg az Egyesült Államokban ez is hozzájárul ahhoz, hogy a tanárok körében nemzetközi összehasonlításban is magas $(27 \%)$ a tanári képesítés nélküli pedagógusok aránya (Feistritzer, 2011), addig Japánban nincs és az elmúlt évtizedekben soha nem is volt tanárhiány, így nem is szorulnak formális képzés nélküli tanárok alkalmazására. Japán esetében a túlképzés (illetve az átlépés a kiegészítő oktatási ipar területére, vagyis a profitorientált oktatási piac egyes szegmenseire), máshol inkább a pedagógus végzettséggel ellátható más munkák nagyobb vonzereje az ok. Angliában, ahol szintén magas a korai pályaelhagyók aránya, különféle tanári szakmai szervezetek, illetve az indukciós, bevezető időszakban a csökkentett óraszám és a szakmai fejlődés külső mentorral történő segítése hivatott csökkenteni ezt az arányt.

A pedagóguspálya nem könnyü, ezért a kezdők segítése, mentorálása, a pálya vonzóvá tétele a legtöbb vizsgált ország oktatáspolitikájában fontos tényező. Az egyik ilyen tényezö, amely a legtöbb országban megjelenik, a gyakornoki rendszer: Ausztria, Németország, Anglia, Japán, Szingapúr, Szerbia is él ezzel a módszerrel. 
A gyakornoki idő hossza változó, jellemzően egy év (pl. Ausztria, Szerbia), de például Németország egyes tartományaiban két év. Ez alatt az idő alatt általában az iskolában tanító tapasztalt kolléga mentorálja a kezdő tanárt, valamint könnyített óraterhelés, esetleg plusz egyetemi szemináriumok segítik a pályakezdőt. Nem jellemző a pedagógus diplomával más pálya felé orientálódás Finnországban és Szingapúrban, ahol a szakma elismertsége (mind társadalmi, mind pedig anyagi téren), az elköteleződés, a kezdő tanárok szakmai támogatása és a könnyített munkaterhelés együtt azt eredményezi, hogy a végzettek a pályán kezdenek el dolgozni. Németországban a gyakornoki év(ek) bevezetésével jelentösen csökkent a korai pályaelhagyók aránya a korábbi időszakhoz képest, amikor a pályakezdők nem érezték magukat megfelelően felkészültnek a gyerekekkel, szülőkkel való kommunikáció terén, a konfliktuskezelésben.

Abban is jelentős eltérések mutatkoznak az egyes országok között, hogy a pályakezdő milyen státuszba kerül. Japánban például a pályakezdőknek tartományi bizottságok előtt szigorú vizsgáztatási procedúrán kell keresztül menniük, mielőtt munkába állnának. Az Egyesült Államokban és Szerbiában is csak a gyakornoki idő után, vizsga letételével kapnak véglegesített tanári státuszt (licenciát, certifikációt). Ezzel ellentétben például Finnországban, Hollandiában, Szingapúrban a végzettek azonnal pedagógusi státuszt kapnak. Szingapúrban például szigorú karriermenedzselési rendszer van, erős a szakmai öntudat, és ez áthagyományozódik a pályakezdőkre. Ausztriában a pedagógiai föiskola elvégzése után rögtön munkába állnak a tanító- és óvóképzést végzettek, míg a szaktanári egyetemi végzettséggel csak egy éves gyakorlat után kezdhetik a pályát.

A tanári pálya választásának népszerüsítését elősegítő intézkedések, programok között kell megemlítenünk a más pályáról belépők ösztönzésének stratégiáit is: Hollandiában, Angliában, Szerbiában, az Egyesült Államokban találkoztunk erre vonatkozó példákkal. Hollandiában azzal ösztönzik a más pályáról pedagóguspályára lépést, hogy bérezésben az utolsó munkahelyének megfelelő szintet kapják a jelentkezők, ezzel elismerve a korábbi munkatapasztalataikat. Angliában a „Premier plus " program ${ }^{7}$ hivatott a más pályáról tanári pályára lépők ösztönzésére, valamint erős szakmai támogató rendszerek segítik az ilyen módon a pedagógusi pályára pályakezdőket. Az Egyesült Államokban a már említett „,TEACH” program, valamint az ehhez kapcsolódó „RESPECT"8 segítenek (U.S. Department of Education, 2013) a később pályára lépők számára is népszerüsíteni a tanári hivatást. Szerbiá-

\footnotetext{
${ }^{7}$ URL: https://getintoteaching.education.gov.uk/premier-plus Letöltés ideje: 2016. 01. 02.

8 A RESPECT (Recognizing Educational Success, Professional Excellence, and Collaborative Teaching) a tanári pályával kapcsolatos olyan szövetségi szintủ elképzelés az oktatás jövőjéről, amely végső céljául azt tủzte ki, hogy a tanári pálya a leginkább elismert professzió legyen az Egyesült Államokban. Mindezt javaslatok, társadalmi viták, népszerüsítő programok és hasonló eszközök segítségével igyekszik megvalósítani. Bővebben URL: http://www2.ed.gov/documents/respect/blueprint-forrespect. pdf Letöltés ideje: 2016. 01. 02.
} 
ban például probléma a nemzetiségi nyelvü (jellemzően magyar) oktatás, ezért kormányzati szinten foglalkoznak a más országban szerzett tanári diplomák honosításának megkönnyítésével, valamint a más jellegü egyetemi diplomával rendelkezők számára 30 kredit pedagógiai, pszichológiai tanulmányok elvégzésével lehetővé teszik, hogy az adott szakterületen (jellemzően a szakközépiskolai, szakiskolai képzésben) tanárként helyezkedjenek el.

\section{A pedagógusok pályán maradását elösegitő, retenciós tevékenységek}

A már gyakorló tanárok pályán tartásának talán leginkább általános formája - szinte mindegyik országra jellemző valamilyen változatban - a szakmai, módszertani, pedagógusi kompetenciák fejlesztésére irányuló továbbképzések rendszere. Ezek formája (kötelező vagy önkéntes, államilag szervezett vagy felsőoktatási intézmények, szakmai szervezetek által szervezett), időtartama, tartalma változatos formákat mutat a vizsgált országokban. Ausztriában például a szakmai és didaktikai ismeretek szinten tartására, illetve új szakterületek megismerésére évi 15 óra kötelező továbbképzést kell teljesíteni a tanároknak, ezekben kiemelten új kompetenciák kialakítása (speciális pedagógiai feladatok, adminisztratív, vezetői feladatok, mentorálás, gyakorlóiskolai tanítás stb.) szerepelnek. Németországban a továbbképzések a pedagógus kompetenciák fejlesztését és új szakirányok elsajátítását célozzák, részei a pályamodellnek, a hivatalos előmenetel alapját képezik. Finnországban a folyamatos szakmai fejlődés biztosítása az iskolavezetők felelőssége, a fejlődés koncepciójának erősítése érdekében átfogó nemzeti szintủ ajánlásokat fogalmaz meg az oktatási kormányzat, a kötelező továbbképzések évente három-öt naposak, de vannak önkéntes programok is, melyeket az állam támogat. Az oktatási rendszer alapvetően bizalmi viszonyokon alapul: az állam, az iskola vezetősége hisz a tanárok felelős gondolkodásában, abban, hogy jól felfogott érdekük a folyamatos szakmai fejlődés. Ösztönzik a tanárokat a tanárképző egyetemekkel közös projektekben, pedagógiai kutatásokban való részvételre, ami szintén a szakmai fejlődést szolgálja. Az Egyesült Államokban például a Milken Family Foundation által megvalósított iskolavezetési módszer, a Teacher Advancement Program $\left(T A P^{9}\right)$ célja az, hogy a tehetséges embereket bevonzza a tanári pályára, és megtartsa őket az osztálytermi tanításban. A programnak négy fỏ eleme van: az összetett karrierút (többféle életpálya lehetőség), a folyamatos szakmai fejlödés, a nevelésközpontú pedagógia, ugyanakkor a tanulók sztenderdizált vizsgákon elért eredményei alapján történő elszámoltathatóság és a teljesítményalapú ösztönzés. Fontos tényező az iskolákon belüli kollaboratív szakmai munka, melyet kreditekben vagy óraszámban

\footnotetext{
${ }^{9}$ Mint számos hasonló alapítványi oktatásügyi program, a TAP sem szövetségi vagy állami szinten müködik, hanem csak a Milken Family Foundation-nel együttmüködő szervezetek szintjén. Bővebben lásd URL: http://www.infoagepub.com/products/downloads/tap_overview.pdf Letöltés ideje: 2016. 01.02 .
} 
a továbbképzésekben megjelenítenek. Szerbiában szintén kötelező továbbképzéseket szerveznek a tanárok számára, szigorú pontrendszerrel. Az akkreditált továbbképzések (a kormányzat által meghatározott stratégiai területeken) mellett azonban beleszámítják az iskolán belüli szakmai munkát, a közös megbeszéléseket, szimpóziumokon, konferenciákon való részvételt és a szakmai tanulmányutakat (melyeket az állam valamilyen mértékben támogat).

A továbbképzési kínálatot és a munkalehetőségeket jellemzően internetes portálokon teszik közzé: például Angliában a „REFLECT” és a „,Golden Hello” programok portáljai, az Egyesült Államokban például a „TAP” honlapjai ${ }^{10}$, Szerbiában a „Vajdasági Módszertani Központ” honlapja ${ }^{11}$, Ausztriában és Németországban a CCT portálok. Ezeknek a portáloknak a müködése széles szakmai összefogáson, folyamatos frissítésen és naprakész adatbázisokon alapul.

Lényeges szerepet játszanak a tanárok pályán tartásában a különböző szakmai segítö szervezetek Angliában, Ausztriában, Németországban, az Egyesült Államokban, Szerbiában, Szingapúrban. Ezen szakmai szervezetek feladata nemcsak a szakmai fejlődés elősegítése, továbbképzések szervezése, hanem a tanári pálya elismertségének növelése is. Ausztriában és Németországban például a „CCT” portálokon olyan tartalmak is megjelennek, melyek a tanári közösségeket segítik projektközpontok müködtetésével, partneri kapcsolatok kiépítését támogatják külföldi továbbképző intézményekkel, az európai uniós projektekben való közreműködés lehetöségeivel. Minőségbiztosítási tanácsadást végeznek a szervezet- és iskolafejlesztés területén, külső szakértői segítséget nyújtanak az iskoláknak képzési normák, értékelés, módszertani ismeretek, kommunikáció, konfliktuskezelés stb. területeken.

Az Egyesült Államokban a tanári pálya elismertségének növelésére a „RESPECT”, elképzelést hirdette meg a szövetségi kormányzat - ennek elemei például az ösztöndíjak és díjak kiemelkedő tanárok számára. Ehhez hasonló programok egyébként az egyes államok szintjén is találhatók. Hollandiában hasonló stratégiával próbálják elérni a tanárok pályán maradását: $a$ „Hollandia tanára" ösztöndíj bevezetésével, amelynek célja a tanárok szakmai fejlődésének elősegítése, szaktudásuk mélyítése, illetve további specializálódása - ez az ösztöndíj maximálisan három évre adható, egy tanárnak 3500 euró értékben.

Szingapúrban szakmai hálózatok széles spektruma (tanári tanulókörök, szakmai workshopok, konferenciák, publikációk, website-ok, jóléti programok) segíti a pedagógusok fejlődését és az előmeneteli rendszerben való haladásukat.

Japánban a hivatalos oktatási rendszernek az ,árnyékoktatás”-sal, a kiegészítő magánoktatás-iparral (például a felvételi előkészítő magánintézményekkel) kell szembenéznie: a profitorientált oktatási magánipar az állam által képzett tanárokat

\footnotetext{
${ }^{10}$ URL: http://www.champlain.edu/career-success/career-transition-programs/teacher-apprenticeshipprogram Letöltés ideje: 2016.01.02.

11 URL: http://vmk.rs/ Letöltés ideje: 2016. 01. 02.
} 
célozza meg piaci fizetésekkel, átcsábítja a legjobbakat, „sztártanárokkal” hirdetve az államinál magasabb színvonalú oktatást minden szinten. Ezeken felül „házitanítói” képzéseket, átképzéseket szerveznek piaci alapokon. A hivatalos oktatáspolitika nehezen veszi fel ezekkel a versenyt, valamint nincs ráhatása a minőség biztosítására.

A pedagógus életpályamodell mint pályán tartó erő ugyancsak nagy különbségeket mutat a vizsgált országok tekintetében. A pedagógusok előmeneteli rendszerében standardok jelennek meg Ausztria, Hollandia, Japán, Szingapúr, Szerbia oktatási rendszerében, de például Finnországban vagy Németországban ez nem jellemző. Németországban feszültséget okoz a tanárok között az, hogy tartományonként eltérő lehet a tanárok státusa: van, ahol köztisztviselöi, van, ahol közalkalmazotti státuszuk van, ami nagyon eltérö béreket és kedvezményeket jelenthet). Nagyon érdekes a szingapúri rendszer, melyben a pedagóguspálya szakmai „sínek” („track”-ek) mentén alakul: tanítási, vezetői, specialista szerepekben határozzák meg a tanári pályát; évente minősítik a tanárokat (erős szakmai támogató rendszert biztosítanak a fejlődés elősegítésére a „TEACH” programmal) és az előmenetel, fejlődés alapján piaci javadalmazást kapnak a tanárok.

Ismeretes, hogy a pedagóguspálya elhagyásának egyik fontos tényezője a kiégés; az utóbbi évtizedekben Angliában, Németországban, Hollandiában ez volt a tanárhiány egyik legfontosabb oka. Ezért a szakmai segítő szervezetek, valamint az oktatáspolitika nagy hangsúlyt fektet az ez ellen való küzdelemre: Angliában a „,coaching” és a kortárs mentorálás segít ennek enyhítésében, Hollandiában a tanárképzésben fordítanak nagyobb hangsúlyt a pályán a tanárokat érö „valóságsokk" elhárítására, Németországban a továbbképzésekben egyre gyakrabban jelennek meg a pedagógusok mentális egészségével foglalkozó kurzusok.

A tanári pálya társadalmi presztízse, elismertsége, anyagi javadalmazása nagyon különböző a vizsgált országokban. Nyilvánvaló azonban, hogy a magas elismertségnek erős a pályán tartó szerepe, melyet sok ország felismert és stratégiai fontosságúnak tart. Ez az általunk vizsgált országok közül jól látható például $J a$ pán, Szingapúr, Finnország esetében.

\section{Összegzés}

Az összehasonlító elemzéseknek ebben a $4 \times 9$-es mátrixában nagyon sok érdekes és elgondolkodtató összefüggés jelent meg, melyet még további elemzések követhetnek - és amelyek közül most csak néhánnyal foglalkoztunk. Sok a nemzeti sajátosságokra építő egyedi elem, de láthattunk közös, szinte mindenhol megjelenő népszerüsítő stratégiákat is. Minden szegmens esetében azokat az elemeket emeltük ki, amelyek valamilyen szempontból különlegesek, érdekesek, esetleg követhető mintát mutatnak. Bemutattuk az egyes országok sajátos problémáit és azokra adott válaszaikat. A pedagógusszakma és -pálya választása és folytatása szempontjából 
fontos négy időszak mindegyikében találhatunk az összehasonlításban olyan elemeket, melyek a magyar köznevelés viszonyaira is adaptálhatók, természetesen figyelembe véve a nemzeti oktatási rendszer sajátosságait ${ }^{12}$.

\section{Irodalom}

Darling-Hammond, L. (2008): Teaching and the Change Wars: The professionalism hypothesis. In: Hargreaves, A. és Fullan, M. (szerk.): Change wars. Solution Tree, Bloomington, 44-68.

Feistritzer, C. E. (2011): Profile of teachers in the U.S. 2011. National Center for Education Information, Washington.

Hoyle, E. (2001): Teaching: Prestige, status and esteem. Educational Management, Administration, and Leadership, 29. sz. 139-152.

Tucker, M. S. (2008): Industrial benchmarking: A research method for education. In: Hargreaves A. és Fullan, M. (szerk.): Change Wars. Solution Tree, Bloomington, 117-133.

U.S. Department of Education (2013): A blueprint for R.E.S.P.E.C.T.: Recognizing educational success, professional excellence and collaborative teaching. U.S. Department of Education, Washington.

\section{Internetes források}

URL: http://www.cct-germany.de/ Letöltés ideje: 2016. 01. 02.

URL: https://www.feadvice.org.uk/want-work-sector-i-want-be-teacher-fe-incentives-newteachers/fe-golden-hello-scheme Letöltés ideje: 2016.01. 02.

URL: http://www.teachfirst.org.uk/ Letöltés ideje: 2016. 01.02.

URL: http://www.monitor-lehrerbildung.de/web/ Letöltés ideje: 2016. 01. 02.

URL: https://www.teach.org/ Letöltés ideje: 2016.01. 02.

URL: https://getintoteaching.education.gov.uk/premier-plus Letöltés ideje: 2016. 01.02.

URL: http://www2.ed.gov/documents/respect/blueprint-for-respect.pdf Letöltés ideje: 2016. 01.02 .

URL: http://www.infoagepub.com/products/downloads/tap_overview.pdf Letöltés ideje: 2016. 01.02.

URL: http://www.champlain.edu/career-success/career-transition-programs/teacher-apprenticeship-program Letöltés ideje: 2016. 01. 02.

URL: http://vmk.rs/ Letöltés ideje: 2016. 01. 02.

\footnotetext{
12 Tanulmányunk elkészítéséhez a TÁMOP-kutatást lefolytató munkacsoport országtanulmányaiban fellelhető adatokat használtuk fel széles merítésben. Mivel azonban e források mindegyike jelenleg még kézirat, bibliográfiánkban nem tüntettük fel őket külön-külön.
} 